\title{
Molecular Pathways Bridging Frontotemporal Lobar Degeneration and Psychiatric Disorders
}

\author{
Roberta Zanardini ${ }^{\dagger}$, Miriam Ciani $^{\dagger}$, Luisa Benussi and Roberta Ghidoni* \\ Molecular Markers Laboratory, IRCCS Istituto Centro San Giovanni di Dio, Fatebenefratelli, Brescia, Italy
}

The overlap of symptoms between neurodegenerative and psychiatric diseases has been reported. Neuropsychiatric alterations are commonly observed in dementia, especially in the behavioral variant of frontotemporal dementia (bvFTD), which is the most common clinical FTD subtype. At the same time, psychiatric disorders, like schizophrenia (SCZ), can display symptoms of dementia, including features of frontal dysfunction with relative sparing of memory. In the present review, we discuss common molecular features in these pathologies with a special focus on FTD. Molecules like Brain Derived Neurotrophic Factor (BDNF) and progranulin are linked to the pathophysiology of both neurodegenerative and psychiatric diseases. In these brain-associated illnesses, the presence of disease-associated variants in BDNF and progranulin (GRN) genes cause a reduction of circulating proteins levels, through alterations in proteins expression or secretion. For these reasons, we believe that prevention and therapy of psychiatric and

OPEN ACCESS

Edited by: Isidro Ferrer,

University of Barcelona, Spain

Reviewed by: Catarina Oliveira, University of Coimbra, Portugal Marc A. Wollmer, Semmelweis University, Germany

${ }^{*}$ Correspondence: Roberta Ghidoni rghidoni@fatebenefratelli.eu

tThese authors have contributed equally to this work.

Received: 13 November 2015 Accepted: 12 January 2016 Published: 01 February 2016

Citation:

Zanardini R, Ciani M, Benussi L and Ghidoni R (2016) Molecular Pathways Bridging Frontotemporal Lobar Degeneration and Psychiatric

Disorders.

Front. Aging Neurosci. 8:10. doi: 10.3389/fnagi.2016.00010 neurological disorders could be achieved enhancing both BDNF and progranulin levels thanks to drug discovery efforts.

Keywords: BDNF, progranulin, biomarkers, frontotemporal dementia, psychiatric disorders, neurodegenerative diseases

\section{INTRODUCTION}

Over the past 10 years frontotemporal lobar degeneration (FTLD) has emerged, along with Alzheimer disease (AD), as a leading cause of dementia developing in midlife or earlier (Ratnavalli et al., 2002; Onyike and Diehl-Schmid, 2013). Identification of FTLD-causing genetic alterations has been complex due to the variety of genes involved and the different protein functions. While the majority of FTLD cases are sporadic, approximately $40 \%$ of patients have a positive family history (Gass et al., 2012) and about 10\% show a clear autosomal-dominant inheritance, suggesting the involvement of genetic components in the etiology of this disorder (Snowden et al., 2002; Seelaar et al., 2008; Rohrer et al., 2009; Benussi et al., 2015). Genetic studies have identified several genes linked to FTLD: microtubule-associated protein tau (MAPT), progranulin (GRN), TAR DNA-binding protein 43 (TDP-43), valosin-containing protein $(V C P)$, charged multivesicular body protein $2 \mathrm{~B}(\mathrm{CHMP} 2 \mathrm{~B})$, fused in sarcoma (FUS), and the hexanucleotide repeat expansion in intron 1 of the chromosome 9 open reading frame 72 (C9ORF72; Hutton et al., 1998; Watts et al., 2004; Skibinski et al., 2005; Baker et al., 2006; Cruts et al., 2006; Broustal et al., 2010; DeJesus-Hernandez et al., 2011; Renton et al., 2011; Rohrer et al., 2015). The neuropathology of FTLD is heterogeneous and subtypes can be distinguished depending on the protein deposited in inclusion bodies in the central nervous system (CNS; Mackenzie et al., 2010). These protein inclusions within neurons and glial cells together with degeneration of the brain's frontal and 
temporal lobes are considered the primary neuropathological hallmark of FTLD (Gass et al., 2012). The most common clinical subtype of frontotemporal dementia is the behavioral variant (bvFTD), which is characterized by progressive behavioral changes, such as disinhibition, apathy/inertia, loss of sympathy/empathy, perseverative, stereotyped and compulsive/ritualistic behavior and hyperorality (Rascovsky et al., 2011). These psychiatric symptoms in FTLD mutation carriers can be very similar to those seen in nonneurodegenerative psychiatric illness (Block et al., 2015). Thus, bvFTD can mimic several psychiatric conditions, such as mood disorders (MD), obsessive-compulsive disorder (OCD) and schizophrenia (SCZ; Wylie et al., 2013). In parallel, some psychiatric disorders, notably SCZ, can progress to a syndrome of dementia that includes features of frontal dysfunction with relative sparing of memory (Friedman et al., 2001; Harvey, 2012). Moreover, bvFTD behavioral symptoms are often controlled by therapies that are available for psychiatric disorders, while no medication has been found to stabilize or improve their cognitive dysfunction (Vossel and Miller, 2008). A similar overlap of symptoms with psychiatric disorders has been observed not only in bvFTD, but also in other forms of dementia such as AD and Lewy Bodies Dementia (LBD). Neuropsychiatric symptoms, such as apathy, depression, delusion, aggression, physical and verbal agitation, are frequent in $\mathrm{LBD}$ and $\mathrm{AD}$, even in the early stages of the disease, and are very distressing to patient caregivers (Nagahama et al., 2010; Lyketsos et al., 2011).

There is a pressing need to identify molecular pathways underlying neuropsychiatric symptoms in psychiatric disorders and dementias. Molecular links between neurodegeneration and psychiatric phenotype have been reported: (i) a recent study shows a decrease of progranulin plasma levels in subjects with bipolar disorder (BD; Kittel-Schneider et al., 2014); (ii) new data have suggested a role of amyloid-beta $(A \beta)$ oligomers in memory impairment, depressive and anhedonic behavior in mice (Ledo et al., 2013); and (iii) transgenic mice overexpressing alphasynuclein-involved in Parkinson's disease and LBD—show lateonset anxiety behavior (Campos et al., 2013) and extracellular alpha-synuclein oligomers modulate synaptic transmission and impair Long Term Potentiation (LTP) via NMDA-receptor activation (Diógenes et al., 2012). The serotonergic system, classically involved in the depression/anxiety mechanisms, is now proposed to regulate $A \beta$ precursor protein (APP) activity and metabolism (Shen et al., 2011), while Brain Derived Neurotrophic Factor (BDNF) has a relevance not only in MD, but also in depression-associated cognitive decline (Diniz et al., 2014). In vivo evidence suggests that $\mathrm{A} \beta$ aggregation dramatically influence BDNF cerebrospinal fluid (CSF) level in transgenic AD mouse models (Peng et al., 2009), underlining the importance of this neurotrophic factor in $\mathrm{AD}$ pathogenesis, as already suggested by genetic studies (Ventriglia et al., 2002; Chen et al., 2014). Moreover, a peculiar CSF A $\beta$ peptide signature was associated to cognitive decline in SCZ, suggesting a dysmetabolism of APP also in this psychiatric disorder (Frisoni et al., 2011; Albertini et al., 2012). In addition, experimental studies showed that the levels of progranulin were significantly correlated with amyloid amount in mouse models of $\mathrm{AD}$, detecting an increase of its levels in mice with extensive dense-core plaques (Minami et al., 2014).

Thus, mechanisms underlying neurodegenerative diseases and psychiatric disorders converge on the same proteins within different pathways. In this review, we will focus on the role of $\mathrm{BDNF}$ and progranulin in these pathologies.

\section{OUR PROTAGONISTS}

BDNF is the most studied and characterized neurotrophin in the CNS and it has received remarkable attention from clinicians because of its importance in the development and maintenance of normal brain functions. In humans, the BDNF gene is located on the short arm of chromosome 11p13 (Pruunsild et al., 2007). The gene comprises 11 exons, each coding for the $5^{\prime}$ untranslated region, spliced to a common downstream $3^{\prime}$ exon IX. BDNF is the result of translation of at least 34 mRNA transcripts and its expression is under the control of nine alternative tissue-specific promoters (Pruunsild et al., 2007). BDNF peptide is synthesized as its pro-isoform (pro-BDNF); proteolytical cleavage into its mature form occurs within the neuron or extracellularly, after secretion (Barker, 2009). Whereas pro-isoforms such as pro-BDNF bind to p75 neurotrophin receptor $\left(\mathrm{p} 75^{N T R}\right)$, the mature neurotrophins bind to proteinkinase neurotrophin receptors-namely tropomyosine-related kinase (Trk) receptors (Huang and Reichardt, 2003). BDNF binds to Trk B of the family of Trk receptors, a process that activates survival mechanisms in the CNS such as proliferation, growth, and neuroplasticity (Islam et al., 2009; Nguyen et al., 2009). In contrast, pro-BDNF activates apoptotic pathways after binding to p75 ${ }^{\text {NTR }}$ (Teng et al., 2005) and induce neuronal remodeling including axonal and dendritic pruning (Barker, 2009; Koshimizu et al., 2009). BDNF, also thanks to its notable activity-dependent regulation of expression and secretion, seems to play an important role in neuronal plasticity, defined as a set of mechanisms that may conduct to neuronal reshaping, birth of new neurons and formation of novel synapses (Bramham and Messaoudi, 2005). This is especially important since growing evidence suggests a role for BDNF in the pathophysiology of brain-associated illnesses including both neurodegenerative and psychiatric diseases (Nagahara and Tuszynski, 2011).

Progranulin is a multi-functional secreted adipokine of 593 amino acids with trophic, anti-inflammatory and growth factor-like properties, characterized by dynamic changes in the expression level, glycosylation status and cellular localization during development and in the adult organism (Daniel et al., 2000, 2003; Petkau et al., 2010). The human progranulin gene $(G R N)$ is located on chromosome 17q21.32 and it is composed of 12 protein-coding exons. Alternative splicing and exon skipping define three different progranulin isoforms (Bhandari and Bateman, 1992; Bhandari et al., 1992). The protein is characterized by a signal sequence and a series of seven and a half granulin repeats (De Muynck and Van Damme, 2011) separated by interlinked spacer regions, which are composed of highly conserved tandem repeats of a unique 12-cysteine motif (Shoyab et al., 1990; Bhandari and Bateman, 1992; 
Bhandari et al., 1992). After secretion, in peripheral tissues the proteolytic cleavage of progranulin at the intra-linker spacer regions give rise to several $\sim 6 \mathrm{kDa}$ peptides called granulins (Butler et al., 2008; Kessenbrock et al., 2008; Bai et al., 2009). However, the full length progranulin can be preserved from cleavage by secretory leukocyte protease inhibitor (SLPI; Zhu et al., 2002) and high-density lipoprotein (HDL)/Apolipoprotein A-I complex (Okura et al., 2010). Both progranulin precursor and its cleavage fragments are biologically active in a series of physiologic and pathological processes, showing opposing roles in different biological functions (De Muynck and Van Damme, 2011). Progranulin protein has many roles inside and outside the brain, acting through the extracellular signalregulated kinase and phosphatidylinositol-3-kinases pathways (Toh et al., 2011). Progranulin is involved in multiple biological functions, such as in survival, migration and regulation of cellular proliferation, wound repair and inflammation, and it has also been speculated to play a role in excitotoxicity and synaptic transmission (Guo et al., 2010; Tapia et al., 2011). Specifically, in the CNS, progranulin seems to play a significant role in maintaining physiological functions because it has been observed that it has neuroprotective effects (Van Kampen et al., 2014) and neurotrophic activity in vitro and in vivo model systems (Van Damme et al., 2008; Gao et al., 2010; Laird et al., 2010). Multiple evidence supports that progranulin is involved in different pathological conditions, such as neurodegenerative, psychiatric and metabolic disorders, thus becoming a fascinating target for therapy (Philips et al., 2010; Petkau and Leavitt, 2014; Kanazawa et al., 2015).

Taken together these data highlight neurotrophic properties for both BDNF and progranulin with a significant role in synaptic density and morphology. Further cellular and molecular studies indicate similar functions and participation in common pathways for our protagonists. The identification of sortilin 1 (SORT1) as the principal neuronal receptor for progranulin was important for our understanding of progranulin biology. SORT1 is a sorting protein involved in endocytosis and transport to trans-golgi network and endosomes: when progranulin is bound to SORT1 it is immediately endocytosed and delivered to the lysosome. Indeed, the uptake of progranulin via SORT1 defines a substantial reduction of extracellular progranulin levels (Petersen et al., 1997). Recently, a determinant role for SORT1 has been described in the pathogenesis of FTLD: deletion of this receptor results in a 2.5 to 5 -fold increase in progranulin levels and reversal of progranulin deficiency in the GRN \pm FTLD model (Hu et al., 2010). Thus, SORT1 is an important regulator of progranulin extracellular levels, while the neurotrophic and neuroprotective effects of progranulin are independent from its uptake mediated by SORT1 receptor (De Muynck et al., 2013). Of note, SORT1 also plays an important role in the biological function of BDNF. It plays an essential role in the regulation of BDNF levels through modulation of both anterograde and lysosomal trafficking (Chen et al., 2005; Evans et al., 2011). Moreover, SORT1 can form a complex with p $75^{N T R}$ and ProBDNF to induce cell death; on the other hand, SORT1 has also been implicated in anterograde trafficking of the Trk receptors from the soma to the nerve terminal, thereby positively regulating BDNF signaling and cell survival (Vaegter et al., 2011).

The presence of common function of the two proteins is further supported by a recent study reporting that progranulin is co-localized with dense-core vesicle markers and is further recruited to synapses following neuronal activity. Furthermore, the authors observed that, similarly to what is described for BDNF, progranulin is secreted from axons and dendrites in an activity-dependent manner with different temporal profiles of secretion. Treatment of neurons with recombinant progranulin was shown to increase synapse density, while decreasing the size of the presynaptic compartment and specifically the number of synaptic vesicles per synapse (Petoukhov et al., 2013). In parallel, a study has demonstrated that acute and gradual increases in BDNF concentration activate different intracellular cascades, leading to differences in spine morphology (Ji et al., 2010). These results suggest that it is not only the concentration of secreted BDNF that it is important for the regulation of neuronal function and morphology, but also the manner in which it is secreted: constitutively or in response to neuronal activity. It is possible that constitutive and regulated secretion of progranulin also differentially regulates synapse structure and function.

\section{BDNF AND PROGRANULIN IN FTLD AND RELATED NEURODEGENERATIVE DISEASES}

Current hypotheses state that the crucial point in the progression of neurodegenerative diseases is driven by deterioration of synapses. This is supported by synapse loss being observed as a major pathophysiological hallmark in all neurodegenerative diseases. BDNF, thanks to its role in synaptogenesis, becomes the best pawn on the chessboard with respect to counteracting synaptic function loss. A reduction of hippocampal BDNF levels not only reduced the number of synapses, but also impaired LTP and caused deficits in the formation and consolidation of hippocampus-dependent memory (Linnarsson et al., 1997; Ma et al., 1998; Mu et al., 1999).

Neurotrophins can protect synapses against various toxic insults in animal models of neurodegenerative diseases, such as $\mathrm{AD}$, Huntington's disease, Amyotrophic Lateral Sclerosis and Parkinson's disease (PD; Nagahara and Tuszynski, 2011). Remarkably, BDNF has been shown to protect and/or repair hippocampal neurons and synapses despite $A \beta$ accumulation and neuronal toxicity in a mouse model of AD (Nagahara et al., 2009) and to rescue plasticity deficits induced by synthetic $A \beta$ oligomers in rat hippocampal slices ex vivo (Zeng et al., 2010). This suggests a therapeutic potential in presence of pathogenic factors (Lu et al., 2013). Furthermore, transplantation of neural stem cells (NSC) secreting BDNF in AD model mice also improved cognitive function (Blurton-Jones et al., 2009). BDNFbased therapy is therefore increasingly expected to ameliorate the symptoms of AD (Nagahara et al., 2009; Peng et al., 2009; Devi and Ohno, 2012; Adachi et al., 2014). Decreased expression levels of BDNF protein and mRNA have been consistently reported in the hippocampus and cortex of individuals with 
AD (Phillips et al., 1991; Connor et al., 1997; Hock et al., 2000; Holsinger et al., 2000) as well as in serum (Laske et al., 2007). Belrose et al. (2014) analyzed neurotrophins alterations in patients with different tauopathies, observing a significant decrease in BDNF mRNA and protein levels in Pick's disease and corticobasal degeneration. A further study on the role of this neurotrophin in different neurological diseases observed lower levels of BDNF protein in serum of FTLD AD, LBD and vascular dementia patients, whereas the protein was increased in PD patients (Ventriglia et al., 2013). In the BDNF gene, a functional polymorphism (SNP, rs6265) has been characterized, producing a valine ( $\mathrm{Val}$ ) to methionine (Met) substitution at the codon 66 (Val66Met) in the proBDNF region. The valine-formethionine substitution is associated with inefficiency inactivitydependent transportation of BDNF mRNA (Chiaruttini et al., 2009) and protein to dendrites (Egan et al., 2003; Chen et al., 2004), thus contributing to reductions in dendritic density, deficits in synaptic connectivity, and neurocognitive deficits (Egan et al., 2003; Chen et al., 2004). Indeed, inheritance of the BDNF Met allele might be expected to confer susceptibility to or modifying the expression of conditions that impact adversely on hippocampal function, as measured also by functional magnetic resonance imaging (Egan et al., 2003; Hariri et al., 2003; Dempster et al., 2005; Nagahara and Tuszynski, 2011).

It has been reported that BDNF Val66Met polymorphism may play a role as a genetic risk factor and diseases modulator for FTLD and may drive a selective damage in specific brain region affected by the disease (Borroni et al., 2012). Due to its role on neuronal function and survival in different systems in the CNS, BDNF is an interesting candidate for drug discovery. Strategies that aim to achieve safe and effective, dose-continuous delivery of BDNF in the brain, as drug-induced increasing BDNF, exercise and diet, epigenetic or peptide mimetic of BDNF, seem promising (Nagahara and Tuszynski, 2011).

Loss-of-function mutations in GRN are a common cause of FTLD. Since 2006, more than 70 distinct pathogenic mutations have been identified in the GRN gene, accounting for up to $20 \%$ of familial and $5 \%$ of sporadic FTLD cases (Cruts et al., 2012). Most of these pathogenic alterations are characterized as nonsense, frameshift and splice site mutations causing a premature stop codon, even if other mechanisms have also been observed (Ghidoni et al., 2008; Gass et al., 2012). All pathogenic mutations identified cause disease by protein haploinsufficiency (Baker et al., 2006; Ghidoni et al., 2008; Finch et al., 2009; Sleegers et al., 2009; Cruts et al., 2012) leading to a $\sim 50 \%$ or greater decrease in progranulin levels in the blood, unaffected brain regions and CSF of GRN mutated subjects (Coppola et al., 2008; Ghidoni et al., 2008, 2012; Finch et al., 2009; Sleegers et al., 2009). Furthermore, circulating progranulin levels have been proposed as a useful biomarker for a quick and inexpensive largescale screening of GRN mutation carriers (Ghidoni et al., 2012). Though all GRN null mutations cause the disease through this common mechanism, linked to the degradation of RNA through non-sense mediated decay (Baker et al., 2006; Cruts et al., 2006), the spectrum of clinical presentations associated with mutations in GRN is heterogeneous: however, the bvFTD is the most common clinical presentation, characterized by progressive behavioral changes (Gass et al., 2006; Rademakers et al., 2007; Beck et al., 2008; Le Ber et al., 2008; Benussi et al., 2009).

In addition to null mutations, GRN polymorphic variants, located in the promoter and in the $3^{\prime}$ untranslated region, have been described to increase the risk to develop FTLD, possibly by influencing the transcription of the gene (Rademakers et al., 2008; Galimberti et al., 2010). The GRN gene expression is also regulated by DNA methylation in its core promoter region (Banzhaf-Strathmann et al., 2013). Interestingly, an increased methylation of GRN promoter region was described in cells and brains from FTLD, specifically in patients with bvFTD clinical variant (Banzhaf-Strathmann et al., 2013; Galimberti et al., 2013). Different lines of GRN-knockout mice have been produced showing phenotypes that qualifiy them as useful models of FTD (Kayasuga et al., 2007; Yin et al., 2010; Ghoshal et al., 2012). Specifically, Yin et al. (2010) obtained progranulin-deficient mice characterized by phenotypic alterations that resembles what is typically observed in patients with bvFTD. All these considerations suggest that progranulin represents a promising target for treatment of different neurodegenerative diseases (Boxer et al., 2013; Van Kampen et al., 2014).

Potential treatments to counteract progranulin loss in neurodegeneration are in development because they could represent a promising therapeutic strategy to decelerate neurodegenerative progression or at least to alleviate the symptoms associated with disease (Gass et al., 2012; Jing et al., 2015). It has been observed that increasing progranulin levels might reduce neuronal vulnerability to injury, inflammation and other insults associated to increased risk of cell death and diseases such as FTLD (Gass et al., 2012). Several chemical compounds, such as Bafilomycin A1 (BafA1), alkalizing compounds and suberoylanilide hydroxamic acid (Capell et al., 2011; Cenik et al., 2011), and genetic factors, including different microRNAs and also different genetic variants (Cruchaga et al., 2011; Finch et al., 2011; van der Zee and Van Broeckhoven, 2011), have recently been identified as enhancer of GRN expression, demonstrating therapeutic potential in progranulin associated- FTLD. Maybe the way to develop an efficacious therapy is still far away, but these first results are encouraging.

\section{BDNF AND PROGRANULIN IN PSYCHIATRIC DISORDERS}

Growing evidences suggest a role for BDNF in the pathophysiology of brain-associated illnesses such as OCD (Maina et al., 2010), attention deficit-hyperactivity disorder (Scassellati et al., 2014), eating disorders (Monteleone et al., 2006) substance abuse (Zanardini et al., 2011) as well as MD, BD and SCZ (Sen et al., 2008; Adachi et al., 2014; Polyakova et al., 2015). Rodent models of depression show reduced expression levels of BDNF and its receptor Tropomyosin receptor kinase $\mathrm{B}$ (TrkB). Different types of stressors on rodents can reduce expression levels of BDNF in amygdala, cortex and hippocampus (Stepanichev et al., 2014). Of note, direct BDNF infusion into the rat midbrain induced antidepressant-like effects (Siuciak et al., 1997). Patients suffering from depression exhibit specific BDNF levels reduction in hippocampus and serum 
(Dwivedi et al., 2003; Bocchio-Chiavetto et al., 2010). Treatments with antidepressant drugs reversed this condition (Sen et al., 2008); this effect was also observed after repetitive transcranial magnetic stimulation, a non-pharmacological intervention (Zanardini et al., 2006). The role of BDNF in BD is unclear, probably because the disease is characterized by different mood states in which the expressiuon of neurotrophin is modulated (Cunha et al., 2006; Yoshimura et al., 2006; de Oliveira et al., 2009; Tramontina et al., 2009). In fact, a recent systematic review and meta-regression analysis reported that peripheral BDNF could be used as a biomarker for mood states and disease progression in BD (Fernandes et al., 2011). Mood stabilizers such as lithium or valproic acid are utilized to treat $\mathrm{BD}$ patients and as happens also for antidepressant, increase the BDNF expression (Hashimoto et al., 2002; Chen and Manji, 2006; Sanacora, 2008). Furthermore, BDNF is also decreased in the prefrontal cortex and hippocampus in an animal model of mania (Frey et al., 2006). In addition, The V66M BDNF allele is strongly associated with BD (Neves-Pereira et al., 2002; Sklar et al., 2002; Lohoff et al., 2005). Moreover, Cattaneo et al. (2010) describe an interesting reduction of BDNF in amniotic fluid of Met carriers (Val/Met and Met/Met) as compared to non carriers (Val/Val), supporting the involvement of this polymorphism in behavioral and functional brain individual differences. Animal studies show that BDNF controls the development and activity of neurotransmitter systems implicated in psychotic disorders (Tanaka et al., 1997; Mattson, 2008). Indeed, neurodevelopmental models of SCZ suggest that reduced BDNF may affect synaptic efficiency and connectivity in SCZ that is believed to underlie core behavioral signs and symptoms of the disease (Lipska et al., 2003; Toro et al., 2007; van Haren et al., 2008). There is no widespread agreement on the degree of peripheral BDNF reduction in SCZ, as measured in blood serum or plasma. Most studies report reduced BDNF levels measured in blood from SCZ patients (Toyooka et al., 2002; Pirildar et al., 2004; Grillo et al., 2007; Mackin et al., 2007; Ikeda et al., 2008; Lee and Kim, 2009; Xiu et al., 2009; Jindal et al., 2010), whereas two studies describe higher levels of BDNF concentration in serum of schizophrenic patients compared with healthy controls (Gama et al., 2007; Reis et al., 2008). There are also studies that report no significant difference in BDNF plasma levels in non-medicated SCZ patients compared with controls, while increased BDNF levels observed in these same subjects following antipsychotic treatment (Lee and Kim, 2009). Some studies evidence altered BDNF mRNA and protein levels in prefrontal cortical regions of post-mortem brain tissue of schizophrenic subjects (Durany et al., 2001; Mellios et al., 2009; Wong et al., 2010), with variation reported across different brain regions (Durany et al., 2001; Hashimoto et al., 2005). Several researchers have focused their attention on DNA methylation as a repressive mechanism for $B D N F$ gene expression, potentially linked to pathogenesis of mental diseases (Tsankova et al., 2007; Mill et al., 2008; Fuchikami et al., 2011). Reduced BDNF gene expression in combination with a considerable increase of promoter methylation levels, was selectively detected in $\mathrm{BD}$ type II subjects (BD-II), but not in BD I group (BD-I) with respect to controls. This result confirms a prior study demonstrating that BDNF expression is decreased in chronic or later stages of $\mathrm{BD}$ compared with early stages of disease (Kauer-Sant'Anna et al., 2009). This suggests that attempting to therapies that may be useful to restore a correct degree of methylation could be beneficial (Nan et al., 1998; Fuks et al., 2000; Garcia-Manero et al., 2006; Candelaria et al., 2007). It has been largely demonstrated that mutations in GRN cause FTLD. It is less known that common genetic polymorphisms in this gene are associated with SCZ and bipolar affective disorder (Rademakers et al., 2008; Momeni et al., 2010; Schoder et al., 2010; Galimberti et al., 2012, 2014). A systematic literature analysis reveals that psychosis is a frequent symptom in FTD in the presence of genetic mutations in GRN and C9ORF72 genes (Shinagawa et al., 2014); in C9ORF72 carriers, psychotic symptoms can even predominate at onset and lead to a diagnosis of OBC, SCZ or BD (Rohrer et al., 2015). At present, the effects of progranulin impairment in psychiatric diseases have not yet been studied in specific animal models. However, since (i) mutations in GRN cause bvFTD and (ii) GRN knock-out models are characterized by prominent behavioral disturbances, the study of such animal models could be useful to understand the molecular mechanisms underlying psychiatric disorders (Roberson, 2012). Galimberti et al. performed an association study in which they analyzed the correlation between progranulin gene variations and the risk for developing BD in patients with BD-I and BD-II (Galimberti et al., 2012, 2014): the specific GRN SNP rs5848, which is associated with variation in progranulin levels (Galimberti et al., 2014), resulted to be a protective factor associated with BD-I, but not with BD-II, probably due to different pathogenic mechanisms among the two subtypes of diseases. In addition, they observed progranulin plasma levels significantly lower in the whole BD population compared with controls, even if they did not exclude the effect of the therapy on progranulin levels. This previous finding was confirmed by a larger replication analysis (Kittel-Schneider et al., 2014). Moreover, also in this $\mathrm{BD}$ cohort it has been observed that age has a significant effect on progranulin levels, with increasing levels in higher age, data which is coherent with what previously reported in FTLD patients (Ghidoni et al., 2008). From a clinical point of view, a high phenotypic variability is associated with GRN mutations, even in the same family (Benussi et al., 2009; Momeni et al., 2010; Pietroboni et al., 2011): specifically, Momeni et al. (2010) studied a Latino family in which SCZ and FTD coexisted, suggesting a molecular link between FTD, SCZ and GRN mutations. Another study reported that the morbid risk for SCZ is significantly increased in first-degree relatives of subjects with FTD with respect to first-degree relatives of people with $\mathrm{AD}$; in addition, in three families with a known GRN mutation, there was a co-segregation of mutation and SCZ (Schoder et al., 2010). Though the concomitance of FTD and SCZ has been reported in few family pedigrees, the pathogenic mechanism of loss of function GRN mutations is consistent with the neurodevelopmental hypothesis of SCZ, as the haploinsufficiency exist throughout development and childhood (Rapoport et al., 2005; Fatemi, 2009). Accordingly, progranulin concentrations were significantly higher in pregnant 
women compared to post-partum levels (Todoric et al., 2012), confirming its role during embryonic development (Daniel et al., 2003). In this view, psychiatric disorders might represent a long lasting preclinical phase preceding FTD in some GRN mutation carriers (Momeni et al., 2010). In line with these data, it's important to note that two clinically different GRN mutated FTLD cases (one with bvFTD and one with progressive non fluent aphasia) showed a premorbid BD status (Cerami et al., 2011).

\section{CONCLUDING REMARKS}

In this review, we described how BDNF and progranulin proteins are involved in psychiatric and neurodegenerative diseases. We found that our protagonists share common molecular features in these pathologies. Specifically we noticed that: (i) Circulating BDNF and progranulin protein levels are reduced in pathological conditions: a decrease of BDNF levels was observed in $\mathrm{MD}$ and $\mathrm{BD}$ as well as in FTLD and related disorders; in parallel, a reduction of progranulin was detected not only in GRN-associated FTLD, but also in $\mathrm{BD}$; (ii) for $B D N F$ and GRN genes, the disease-associated variants cause a reduction in protein levels: the BDNF Val66Met polymorphism, a risk factor for BD and FTLD, results in a impaired secretion of the protein; (iii) in parallel, the whole panel of pathogenic GRN mutations as well as polymorphisms cause reduced protein expression or secretion, although by different cellular mechanisms; (iv) both $B D N F$ and GRN promoters are highly

\section{REFERENCES}

Adachi, N., Numakawa, T., Richards, M., Nakajima, S., and Kunugi, H. (2014). New insight in expression, transport and secretion of brain-derived neurotrophic factor: Implications in brain-related diseases. World J. Biol. Chem. 5, 409-428. doi: 10.4331/wjbc.v5.i4.409

Albertini, V., Benussi, L., Paterlini, A., Glionna, M., Prestia, A., BocchioChiavetto, L., et al. (2012). Distinct cerebrospinal fluid amyloid-beta peptide signatures in cognitive decline associated with Alzheimer's disease and schizophrenia. Electrophoresis 33, 3738-3744. doi: 10.1002/elps.201200307

Bai, X. H., Wang, D. W., Kong, L., Zhang, Y., Luan, Y., Kobayashi, T., et al. (2009). ADAMTS-7, a direct target of PTHrP, adversely regulates endochondral bone growth by associating with and inactivating GEP growth factor. Mol. Cell. Biol. 29, 4201-4219. doi: 10.1128/MCB.00056-09

Baker, M., Mackenzie, I. R., Pickering-Brown, S. M., Gass, J., Rademakers, R., Lindholm, C., et al. (2006). Mutations in progranulin cause tau-negative frontotemporal dementia linked to chromosome 17. Nature 442, 916-919. doi: $10.1038 /$ nature 05016

Banzhaf-Strathmann, J., Claus, R., Mücke, O., Rentzsch, K., van der Zee, J., Engelborghs, S., et al. (2013). Promoter DNA methylation regulates progranulin expression and is altered in FTLD. Acta Neuropathol. Commun. 1:16. doi: $10.1186 / 2051-5960-1-16$

Barker, P. A. (2009). Whither proBDNF? Nat. Neurosci. 12, 105-106. doi: 10. 1038/nn0209-105

Beck, J., Rohrer, J. D., Campbell, T., Isaacs, A., Morrison, K. E., Goodall, E. F., et al. (2008). A distinct clinical, neuropsychological and radiological phenotype is associated with progranulin gene mutations in a large UK series. Brain 131, 706-720. doi: 10.1093/brain/awm320

Belrose, J. C., Masoudi, R., Michalski, B., and Fahnestock, M. (2014). Increased pro-nerve growth factor and decreased brain-derived neurotrophic factor in non-Alzheimer's disease tauopathies. Neurobiol. Aging 35, 926-933. doi: 10. 1016/j.neurobiolaging.2013.08.029 methylated in pathological conditions: a different degree of methylation, and consequently a reduction of gene expression, was observed in $B D N F$ and $G R N$ promoter regions in $\mathrm{BD}$ and FTLD, respectively; and (v) equally BDNF and progranulin are involved in neurodevelopment and neuroplasticity: an insult or a genetic defect might unbalance the expression of these neurotrophins in specific brain regions and in different period of life and thus results in either neurodegenerative or psychiatric diseases.

In this view, we may speculate that, as suggested by Momeni et al. (2010) for subjects with progranulin deficit, psychiatric disorders might represent a preclinical phase preceding FTD.

Given all these similarities, we believe that drug discovery effort aimed at enhancing both BDNF and progranulin levels is of great interest for the prevention and cure of psychiatric and neurological disorders.

\section{AUTHOR CONTRIBUTIONS}

All authors contributed to the researching of data for the article, and to the review/editing of the manuscript before submission. $\mathrm{RZ}$ and $\mathrm{MC}$ equally contributed to writing the first draft of the manuscript.

\section{ACKNOWLEDGMENTS}

This work was supported by grant from Ricerca Corrente, Italian Ministry of Health.

Benussi, L., Ghidoni, R., Pegoiani, E., Moretti, D. V., Zanetti, O., and Binetti, G. (2009). Progranulin Leu271LeufsX10 is one of the most common FTLD and CBS associated mutations worldwide. Neurobiol. Dis. 33, 379-385. doi: 10. 1016/j.nbd.2008.11.008

Benussi, A., Padovani, A., and Borroni, B. (2015). Phenotypic heterogeneity of monogenic frontotemporal dementia. Front. Aging Neurosci. 7:171. doi: 10. 3389/fnagi.2015.00171

Bhandari, V., and Bateman, A. (1992). Structure and chromosomal location of the human granulin gene. Biochem. Biophys. Res. Commun. 188, 57-63. doi: 10. 1016/0006-291x(92)92349-3

Bhandari, V., Palfree, R. G., and Bateman, A. (1992). Isolation and sequence of the granulin precursor cDNA from human bone marrow reveals tandem cysteinerich granulin domains. Proc. Natl. Acad. Sci. U S A 89, 1715-1719. doi: 10. 1073/pnas.89.5.1715

Block, N. R., Sha, S. J., Karydas, A. M., Fong, J. C., De May, M. G., Miller, B. L., et al. (2015). Frontotemporal dementia and psychiatric illness: emerging clinical and biological links in gene carriers. Am. J. Geriatr. Psychiatry doi: 10.1016/j.jagp. 2015.04.007 [Epub ahead of print].

Blurton-Jones, M., Kitazawa, M., Martinez-Coria, H., Castello, N. A., Müller, F. J., Loring, J. F., et al. (2009). Neural stem cells improve cognition via BDNF in a transgenic model of Alzheimer disease. Proc. Natl. Acad. Sci. U S A 106, 13594-13599. doi: 10.1073/pnas.0901402106

Bocchio-Chiavetto, L., Bagnardi, V., Zanardini, R., Molteni, R., Nielsen, M. G., Placentino, A., et al. (2010). Serum and plasma BDNF levels in major depression: a replication study and meta-analyses. World J. Biol. Psychiatry 11, 763-773. doi: 10.3109/15622971003611319

Borroni, B., Bianchi, M., Premi, E., Alberici, A., Archetti, S., Paghera, B., et al. (2012). The brain-derived neurotrophic factor Val66Met polymorphism is associated with reduced hippocampus perfusion in frontotemporal lobar degeneration. J. Alzheimers Dis. 31, 243-251. doi: 10.3233/JAD-2012-120226

Boxer, A. L., Gold, M., Huey, E., Gao, F. B., Burton, E. A., Chow, T., et al. (2013). Frontotemporal degeneration, the next therapeutic frontier: molecules and 
animal models for frontotemporal degeneration drug development. Alzheimers Dement. 9, 176-188. doi: 10.1016/j.jalz.2012.03.002

Bramham, C. R., and Messaoudi, E. (2005). BDNF function in adult synaptic plasticity: the synaptic consolidation hypothesis. Prog. Neurobiol. 76, 99-125. doi: 10.1016/j.pneurobio.2005.06.003

Broustal, O., Camuzat, A., Guillot-Noë, L., Guy, N., Millecamps, S., Deffond, D., et al. (2010). FUS mutations in frontotemporal lobar degeneration with amyotrophic lateral sclerosis. J. Alzheimers Dis. 22, 765-769. doi: 10.3233/JAD2010-100837

Butler, G. S., Dean, R. A., Tam, E. M., and Overall, C. M. (2008). Pharmacoproteomics of a metalloproteinase hydroxamate inhibitor in breast cancer cells: dynamics of membrane type 1 matrix metalloproteinase-mediated membrane protein shedding. Mol. Cell. Biol. 28, 4896-4914. doi: 10.1128/MCB. 01775-07

Campos, F. L., Carvalho, M. M., Cristovão, A. C., Je, G., Baltazar, G., Salgado, A. J., et al. (2013). Rodent models of Parkinson's disease: beyond the motor symptomatology. Front. Behav. Neurosci. 7:175. doi: 10.3389/fnbeh.2013.00175

Candelaria, M., Gallardo-Rincón, D., Arce, C., Cetina, L., Aguilar-Ponce, J. L., Arrieta, O., et al. (2007). A phase II study of epigenetic therapy with hydralazine and magnesium valproate to overcome chemotherapy resistance in refractory solid tumors. Ann. Oncol. 18, 1529-1538. doi: 10.1093/annonc/mdm204

Capell, A., Liebscher, S., Fellerer, K., Brouwers, N., Willem, M., Lammich, S., et al. (2011). Rescue of progranulin deficiency associated with frontotemporal lobar degeneration by alkalizing reagents and inhibition of vacuolar ATPase. J. Neurosci. 31, 1885-1894. doi: 10.1523/JNEUROSCI.5757-10.2011

Cattaneo, A., Bocchio-Chiavetto, L., Zanardini, R., Marchina, E., Bellotti, D., Milanesi, E., et al. (2010). BDNF Val66Met polymorphism and protein levels in amniotic fluid. BMC Neurosci. 11:16. doi: 10.1186/1471-2202-11-16

Cenik, B., Sephton, C. F., Dewey, C. M., Xian, X., Wei, S., Yu, K., et al. (2011). Suberoylanilide hydroxamic acid (vorinostat) up-regulates progranulin transcription: rational therapeutic approach to frontotemporal dementia. J. Biol. Chem. 286, 16101-16108. doi: 10.1074/jbc.M110.193433

Cerami, C., Marcone, A., Galimberti, D., Villa, C., Scarpini, E., and Cappa, S. F. (2011). From genotype to phenotype: two cases of genetic frontotemporal lobar degeneration with premorbid bipolar disorder. J. Alzheimers. Dis. 27, 791-797. doi: 10.3233/JAD-2011-110788

Chen, Z. Y., Ieraci, A., Tanowitz, M., and Lee, F. S. (2005). A novel endocytic recycling signal distinguishes biological responses of Trk neurotrophin receptors. Mol. Biol. Cell 16, 5761-5772. doi: 10.1091/mbc.e05-07-0651

Chen, J., Liang, X., Li, B., Jiang, X., and Xu, Z. (2014). Gender-related association of brain-derived neurotrophic factor gene 196A/G polymorphism with Alzheimer's disease-a meta-analysis including 6854 cases and 6868 controls. Int. J. Neurosci. 124, 724-733. doi: 10.3109/00207454.2013.869594

Chen, G., and Manji, H. K. (2006). The extracellular signal-regulated kinase pathway: an emerging promising target for mood stabilizers. Curr. Opin. Psychiatry 19, 313-323. doi: 10.1097/01.yco.0000218604.63463.cd

Chen, Z. Y., Patel, P. D., Sant, G., Meng, C. X., Teng, K. K., Hempstead, B. L., et al. (2004). Variant brain-derived neurotrophic factor (BDNF; Met66) alters the intracellular trafficking and activity-dependent secretion of wild-type BDNF in neurosecretory cells and cortical neurons. J. Neurosci. 24, 4401-4411. doi: 10. 1523/jneurosci.0348-04.2004

Chiaruttini, C., Vicario, A., Li, Z., Baj, G., Braiuca, P., Wu, Y., et al. (2009). Dendritic trafficking of BDNF mRNA is mediated by translin and blocked by the G196A (Val66Met) mutation. Proc. Natl. Acad. Sci. U S A 106, 16481-16486. doi: 10.1073/pnas.0902833106

Connor, B., Young, D., Yan, Q., Faull, R. L., Synek, B., and Dragunow, M. (1997). Brain-derived neurotrophic factor is reduced in Alzheimer's disease. Brain Res. Mol. Brain Res. 49, 71-81. doi: 10.1016/s0169-328x(97)00125-3

Coppola, G., Karydas, A., Rademakers, R., Wang, Q., Baker, M., Hutton, M., et al. (2008). Gene expression study on peripheral blood identifies progranulin mutations. Ann. Neurol. 64, 92-96. doi: 10.1002/ana.21397

Cruchaga, C., Graff, C., Chiang, H. H., Wang, J., Hinrichs, A. L., Spiegel, N., et al. (2011). Association of TMEM106B gene polymorphism with age at onset in granulin mutation carriers and plasma granulin protein levels. Arch. Neurol. 68, 581-586. doi: 10.1001/archneurol.2010.350

Cruts, M., Gijselinck, I., van der Zee, J., Engelborghs, S., Wils, H., Pirici, D., et al. (2006). Null mutations in progranulin cause ubiquitin-positive frontotemporal dementia linked to chromosome 17q21. Nature 442, 920-924. doi: 10. $2174 / 156720506779025251$
Cruts, M., Theuns, J., and Van Broeckhoven, C. (2012). Locus-specific mutation databases for neurodegenerative brain diseases. Hum. Mutat. 33, 1340-1344. doi: 10.1002/humu.22117

Cunha, A. B., Frey, B. N., Andreazza, A. C., Goi, J. D., Rosa, A. R., Gonçalves, C. A., et al. (2006). Serum brain-derived neurotrophic factor is decreased in bipolar disorder during depressive and manic episodes. Neurosci. Lett. 398, 215-219. doi: 10.1016/j.neulet.2005.12.085

Daniel, R., Daniels, E., He, Z., and Bateman, A. (2003). Progranulin (acrogranin/PC cell-derived growth factor/granulin-epithelin precursor) is expressed in the placenta, epidermis, microvasculature and brain during murine development. Dev. Dyn. 227, 593-599. doi: 10.1002/dvdy. 10341

Daniel, R., He, Z., Carmichael, K. P., Halper, J., and Bateman, A. (2000). Cellular localization of gene expression for progranulin. J. Histochem. Cytochem. 48, 999-1009. doi: 10.1177/002215540004800713

DeJesus-Hernandez, M., Mackenzie, I. R., Boeve, B. F., Boxer, A. L., Baker, M., Rutherford, N. J., et al. (2011). Expanded GGGGCC hexanucleotide repeat in noncoding region of C9ORF72 causes chromosome 9p-linked FTD and ALS. Neuron 72, 245-256. doi: 10.1016/j.neuron.2011.09.011

Dempster, E., Toulopoulou, T., McDonald, C., Bramon, E., Walshe, M., Filbey, F., et al. (2005). Association between BDNF val66met genotype and episodic memory. Am. J. Med. Genet. B Neuropsychiatr. Genet. 134B, 73-75. doi: 10. 1002/ajmg.b.30150

De Muynck, L., Herdewyn, S., Beel, S., Scheveneels, W., Van Den Bosch, L., Robberecht, W., et al. (2013). The neurotrophic properties of progranulin depend on the granulin $\mathrm{E}$ domain but do not require sortilin binding. Neurobiol. Aging 34, 2541-2547. doi: 10.1016/j.neurobiolaging.2013. 04.022

De Muynck, L., and Van Damme, P. (2011). Cellular effects of progranulin in health and disease. J. Mol. Neurosci. 45, 549-560. doi: 10.1007/s12031-0119553-z

de Oliveira, G. S., Ceresér, K. M., Fernandes, B. S., Kauer-Sant'Anna, M., Fries, G. R., Stertz, L., et al. (2009). Decreased brain-derived neurotrophic factor in medicated and drug-free bipolar patients. J. Psychiatr. Res. 43, 1171-1174. doi: 10.1016/j.jpsychires.2009.04.002

Devi, L., and Ohno, M. (2012). 7,8-dihydroxyflavone, a small-molecule TrkB agonist, reverses memory deficits and BACE1 elevation in a mouse model of Alzheimer's disease. Neuropsychopharmacology 37, 434-444. doi: 10.1038/npp. 2011.191

Diniz, B. S., Teixeira, A. L., Machado-Vieira, R., Talib, L. L., Radanovic, M., Gattaz, W. F., et al. (2014). Reduced cerebrospinal fluid levels of brainderived neurotrophic factor is associated with cognitive impairment in latelife major depression. J. Gerontol. B Psychol. Sci. Soc. Sci. 69, 845-851. doi: 10. 1093/geronb/gbu096

Diógenes, M. J., Dias, R. B., Rombo, D. M., Vicente Miranda, H., Maiolino, F., Guerreiro, P., et al. (2012). Extracellular alpha-synuclein oligomers modulate synaptic transmission and impair LTP via NMDA-receptor activation. J. Neurosci. 32, 11750-11762. doi: 10.1523/JNEUROSCI.0234-12.2012

Durany, N., Michel, T., Zöchling, R., Boissl, K. W., Cruz-Sánchez, F. F., Riederer, P., et al. (2001). Brain-derived neurotrophic factor and neurotrophin 3 in schizophrenic psychoses. Schizophr. Res. 52, 79-86. doi: 10.1016/s09209964(00)00084-0

Dwivedi, Y., Rizavi, H. S., Conley, R. R., Roberts, R. C., Tamminga, C. A., and Pandey, G. N. (2003). Altered gene expression of brain-derived neurotrophic factor and receptor tyrosine kinase B in postmortem brain of suicide subjects. Arch. Gen. Psychiatry 60, 804-815. doi: 10.1001/archpsyc.60.8.804

Egan, M. F., Kojima, M., Callicott, J. H., Goldberg, T. E., Kolachana, B. S., Bertolino, A., et al. (2003). The BDNF val66met polymorphism affects activitydependent secretion of BDNF and human memory and hippocampal function. Cell 112, 257-269. doi: 10.1016/s0092-8674(03)00035-7

Evans, S. F., Irmady, K., Ostrow, K., Kim, T., Nykjaer, A., Saftig, P., et al. (2011). Neuronal brain-derived neurotrophic factor is synthesized in excess, with levels regulated by sortilin-mediated trafficking and lysosomal degradation. J. Biol. Chem. 286, 29556-29567. doi: 10.1074/jbc.M111.219675

Fatemi, S. H. (2009). Potential microbial origins of schizophrenia and their treatments. Drugs Today (Barc) 45, 305-318. doi: 10.1358/dot.2009.45.4. 1353924

Fernandes, B. S., Gama, C. S., Ceresér, K. M., Yatham, L. N., Fries, G. R., Colpo, G., et al. (2011). Brain-derived neurotrophic factor as a state-marker of mood 
episodes in bipolar disorders: a systematic review and meta-regression analysis. J. Psychiatr. Res. 45, 995-1004. doi: 10.1016/j.jpsychires.2011.03.002

Finch, N., Baker, M., Crook, R., Swanson, K., Kuntz, K., Surtees, R., et al. (2009). Plasma progranulin levels predict progranulin mutation status in frontotemporal dementia patients and asymptomatic family members. Brain 132, 583-591. doi: 10.1093/brain/awn352

Finch, N., Carrasquillo, M. M., Baker, M., Rutherford, N. J., Coppola, G., DejesusHernandez, M., et al. (2011). TMEM106B regulates progranulin levels and the penetrance of FTLD in GRN mutation carriers. Neurology 76, 467-474. doi: 10. 1212/WNL.0b013e31820a0e3b

Frey, B. N., Andreazza, A. C., Ceresér, K. M., Martins, M. R., Valvassori, S. S., Réus, G. Z., et al. (2006). Effects of mood stabilizers on hippocampus BDNF levels in an animal model of mania. Life Sci. 79, 281-286. doi: 10.1016/j.lfs.2006. 01.002

Friedman, J. I., Harvey, P. D., Coleman, T., Moriarty, P. J., Bowie, C., Parrella, M., et al. (2001). Six-year follow-up study of cognitive and functional status across the lifespan in schizophrenia: a comparison with Alzheimer's disease and normal aging. Am. J. Psychiatry 158, 1441-1448. doi: 10.1176/appi.ajp.158.9. 1441

Frisoni, G. B., Prestia, A., Geroldi, C., Adorni, A., Ghidoni, R., Amicucci, G., et al. (2011). Alzheimer's CSF markers in older schizophrenia patients. Int. J. Geriatr. Psychiatry 26, 640-648. doi: 10.1002/gps.2575

Fuchikami, M., Morinobu, S., Segawa, M., Okamoto, Y., Yamawaki, S., Ozaki, N., et al. (2011). DNA methylation profiles of the brain-derived neurotrophic factor (BDNF) gene as a potent diagnostic biomarker in major depression. PLoS One 6:e23881. doi: 10.1371/journal.pone.0023881

Fuks, F., Burgers, W. A., Brehm, A., Hughes-Davies, L., and Kouzarides, T. (2000). DNA methyltransferase Dnmt1 associates with histone deacetylase activity. Nat. Genet. 24, 88-91. doi: 10.1038/71750

Galimberti, D., D’Addario, C., Dell'osso, B., Fenoglio, C., Marcone, A., Cerami, C., et al. (2013). Progranulin gene (GRN) promoter methylation is increased in patients with sporadic frontotemporal lobar degeneration. Neurol. Sci. 34, 899-903. doi: 10.1007/s10072-012-1151-5

Galimberti, D., Dell'Osso, B., Fenoglio, C., Villa, C., Cortini, F., Serpente, M., et al. (2012). Progranulin gene variability and plasma levels in bipolar disorder and schizophrenia. PLoS One 7:e32164. doi: 10.1371/journal.pone.00 32164

Galimberti, D., Fenoglio, C., Cortini, F., Serpente, M., Venturelli, E., Villa, C., et al. (2010). GRN variability contributes to sporadic frontotemporal lobar degeneration. J. Alzheimers Dis. 19, 171-177. doi: 10.3233/JAD-2010-1225

Galimberti, D., Prunas, C., Paoli, R. A., Dell'Osso, B., Fenoglio, C., Villa, C., et al. (2014). Progranulin gene variability influences the risk for bipolar I disorder, but not bipolar II disorder. Bipolar Disord. 16, 769-772. doi: 10.1111/bdi. 12180

Gama, C. S., Andreazza, A. C., Kunz, M., Berk, M., Belmonte-de-Abreu, P. S., and Kapczinski, F. (2007). Serum levels of brain-derived neurotrophic factor in patients with schizophrenia and bipolar disorder. Neurosci. Lett. 420, 45-48. doi: 10.1016/j.neulet.2007.04.001

Gao, X., Joselin, A. P., Wang, L., Kar, A., Ray, P., Bateman, A., et al. (2010). Progranulin promotes neurite outgrowth and neuronal differentiation by regulating GSK-3 $\beta$. Protein Cell 1, 552-562. doi: 10.1007/s13238-010-0067-1

Garcia-Manero, G., Kantarjian, H. M., Sanchez-Gonzalez, B., Yang, H., Rosner, G., Verstovsek, S., et al. (2006). Phase $1 / 2$ study of the combination of 5-aza2 '-deoxycytidine with valproic acid in patients with leukemia. Blood 108, 3271-3279. doi: 10.1182/blood-2006-03-009142

Gass, J., Cannon, A., Mackenzie, I. R., Boeve, B., Baker, M., Adamson, J., et al. (2006). Mutations in progranulin are a major cause of ubiquitin-positive frontotemporal lobar degeneration. Hum. Mol. Genet. 15, 2988-3001. doi: 10. 1093/hmg/ddl241

Gass, J., Prudencio, M., Stetler, C., and Petrucelli, L. (2012). Progranulin: an emerging target for FTLD therapies. Brain Res. 1462, 118-128. doi: 10.1016/j. brainres.2012.01.047

Ghidoni, R., Benussi, L., Glionna, M., Franzoni, M., and Binetti, G. (2008). Low plasma progranulin levels predict progranulin mutations in frontotemporal lobar degeneration. Neurology 71, 1235-1239. doi: 10.1212/01.wnl.0000325058. 10218.fc

Ghidoni, R., Paterlini, A., and Benussi, L. (2012). Circulating progranulin as a biomarker for neurodegenerative diseases. Am. J. Neurodegener Dis. 1, 180-190.
Ghoshal, N., Dearborn, J. T., Wozniak, D. F., and Cairns, N. J. (2012). Core features of frontotemporal dementia recapitulated in progranulin knockout mice. Neurobiol. Dis. 45, 395-408. doi: 10.1016/j.nbd.2011.08.029

Grillo, R. W., Ottoni, G. L., Leke, R., Souza, D. O., Portela, L. V., and Lara, D. R. (2007). Reduced serum BDNF levels in schizophrenic patients on clozapine or typical antipsychotics. J. Psychiatr. Res. 41, 31-35. doi: 10.1016/j.jpsychires. 2006.01.005

Guo, A., Tapia, L., Bamji, S. X., Cynader, M. S., and Jia, W. (2010). Progranulin deficiency leads to enhanced cell vulnerability and TDP-43 translocation in primary neuronal cultures. Brain Res. 1366, 1-8. doi: 10.1016/j.brainres.2010. 09.099

Hariri, A. R., Goldberg, T. E., Mattay, V. S., Kolachana, B. S., Callicott, J. H., Egan, M. F., et al. (2003). Brain-derived neurotrophic factor val66met polymorphism affects human memory-related hippocampal activity and predicts memory performance. J. Neurosci. 23, 6690-6694.

Harvey, P. D. (2012). Clinical applications of neuropsychological assessment. Dialogues Clin. Neurosci. 14, 91-99.

Hashimoto, T., Bergen, S. E., Nguyen, Q. L., Xu, B., Monteggia, L. M., Pierri, J. N., et al. (2005). Relationship of brain-derived neurotrophic factor and its receptor TrkB to altered inhibitory prefrontal circuitry in schizophrenia. J. Neurosci. 25, 372-383. doi: 10.1523/jneurosci.4035-04.2005

Hashimoto, R., Takei, N., Shimazu, K., Christ, L., Lu, B., and Chuang, D. M. (2002). Lithium induces brain-derived neurotrophic factor and activates TrkB in rodent cortical neurons: an essential step for neuroprotection against glutamate excitotoxicity. Neuropharmacology 43, 1173-1179. doi: 10. 1016/s0028-3908(02)00217-4

Hock, C., Heese, K., Hulette, C., Rosenberg, C., and Otten, U. (2000). Regionspecific neurotrophin imbalances in Alzheimer disease: decreased levels of brain-derived neurotrophic factor and increased levels of nerve growth factor in hippocampus and cortical areas. Arch. Neurol. 57, 846-851. doi: 10. 1001/archneur.57.6.846

Holsinger, R. M., Schnarr, J., Henry, P., Castelo, V. T., and Fahnestock, M. (2000). Quantitation of BDNF mRNA in human parietal cortex by competitive reverse transcription-polymerase chain reaction: decreased levels in Alzheimer's disease. Brain Res. Mol. Brain Res. 76, 347-354. doi: 10.1016/s0169$328 \mathrm{x}(00) 00023-1$

Hu, F., Padukkavidana, T., Vaegter, C. B., Brady, O. A., Zheng, Y., Mackenzie, I. R., et al. (2010). Sortilin-mediated endocytosis determines levels of the frontotemporal dementia protein, progranulin. Neuron 68, 654-667. doi: 10.1016/j.neuron.2010.09.034

Huang, E. J., and Reichardt, L. F. (2003). Trk receptors: roles in neuronal signal transduction. Annu. Rev. Biochem. 72, 609-642. doi: 10.1146/annurev.biochem. 72.121801 .161629

Hutton, M., Lendon, C. L., Rizzu, P., Baker, M., Froelich, S., Houlden, H., et al. (1998). Association of missense and $5^{\prime}$-splice-site mutations in tau with the inherited dementia FTDP-17. Nature 393, 702-705. doi: 10.1038/ 31508

Ikeda, Y., Yahata, N., Ito, I., Nagano, M., Toyota, T., Yoshikawa, T., et al. (2008). Low serum levels of brain-derived neurotrophic factor and epidermal growth factor in patients with chronic schizophrenia. Schizophr. Res. 101, 58-66. doi: 10.1016/j.schres.2008.01.017

Islam, O., Loo, T. X., and Heese, K. (2009). Brain-derived neurotrophic factor (BDNF) has proliferative effects on neural stem cells through the truncated TRK-B receptor, MAP kinase, AKT and STAT-3 signaling pathways. Curr. Neurovasc. Res. 6, 42-53. doi: 10.2174/1567202097874 66028

Ji, Y., Lu, Y., Yang, F., Shen, W., Tang, T. T., Feng, L., et al. (2010). Acute and gradual increases in BDNF concentration elicit distinct signaling and functions in neurons. Nat. Neurosci. 13, 302-309. doi: 10.1038/nn.2505

Jindal, R. D., Pillai, A. K., Mahadik, S. P., Eklund, K., Montrose, D. M., and Keshavan, M. S. (2010). Decreased BDNF in patients with antipsychotic naive first episode schizophrenia. Schizophr. Res. 119, 47-51. doi: 10.1016/j.schres. 2009.12.035

Jing, H., Tan, M. S., Yu, J. T., and Tan, L. (2015). The role of PGRN in Alzheimer's disease. Mol. Neurobiol. doi: 10.1007/s12035-015-9358-0 [Epub ahead of print].

Kanazawa, M., Kawamura, K., Takahashi, T., Miura, M., Tanaka, Y., Koyama, M., et al. (2015). Multiple therapeutic effects of progranulin on experimental acute ischaemic stroke. Brain 138, 1932-1948. doi: 10.1093/brain/awv079 
Kauer-Sant'Anna, M., Kapczinski, F., Andreazza, A. C., Bond, D. J., Lam, R. W., Young, L. T., et al. (2009). Brain-derived neurotrophic factor and inflammatory markers in patients with early- vs. late-stage bipolar disorder. Int. J. Neuropsychopharmacol. 12, 447-458. doi: 10.1017/s14611457080 09310

Kayasuga, Y., Chiba, S., Suzuki, M., Kikusui, T., Matsuwaki, T., Yamanouchi, K., et al. (2007). Alteration of behavioural phenotype in mice by targeted disruption of the progranulin gene. Behav. Brain Res. 185, 110-118. doi: 10 . 1016/j.bbr.2007.07.020

Kessenbrock, K., Fröhlich, L., Sixt, M., Lämmermann, T., Pfister, H., Bateman, A., et al. (2008). Proteinase 3 and neutrophil elastase enhance inflammation in mice by inactivating antiinflammatory progranulin. J. Clin. Invest. 118, 2438-2447. doi: 10.1172/JCI34694

Kittel-Schneider, S., Weigl, J., Volkert, J., Gessner, A., Schmidt, B., Hempel, S., et al. (2014). Further evidence for plasma progranulin as a biomarker in bipolar disorder. J. Affect. Disord. 157, 87-91. doi: 10.1016/j.jad.2014.01.006

Koshimizu, H., Kiyosue, K., Hara, T., Hazama, S., Suzuki, S., Uegaki, K., et al. (2009). Multiple functions of precursor BDNF to CNS neurons: negative regulation of neurite growth, spine formation and cell survival. Mol. Brain 2:27. doi: 10.1186/1756-6606-2-27

Laird, A. S., Van Hoecke, A., De Muynck, L., Timmers, M., Van den Bosch, L., Van Damme, P., et al. (2010). Progranulin is neurotrophic in vivo and protects against a mutant TDP-43 induced axonopathy. PLoS One 5:e13368. doi: 10. 1371/journal.pone.0013368

Laske, C., Stransky, E., Leyhe, T., Eschweiler, G. W., Maetzler, W., Wittorf, A., et al. (2007). BDNF serum and CSF concentrations in Alzheimer's disease, normal pressure hydrocephalus and healthy controls. J. Psychiatr. Res. 41, 387-394. doi: 10.1016/j.jpsychires.2006.01.014

Le Ber, I., Camuzat, A., Hannequin, D., Pasquier, F., Guedj, E., Rovelet-Lecrux, A., et al. (2008). Phenotype variability in progranulin mutation carriers: a clinical, neuropsychological, imaging and genetic study. Brain 131, 732-746. doi: 10. 1093/brain/awn012

Ledo, J. H., Azevedo, E. P., Clarke, J. R., Ribeiro, F. C., Figueiredo, C. P., Foguel, D., et al. (2013). Amyloid-beta oligomers link depressive-like behavior and cognitive deficits in mice. Mol. Psychiatry 18, 1053-1054. doi: 10.1038/mp. 2012.168

Lee, B. H., and Kim, Y. K. (2009). Increased plasma brain-derived neurotropic factor, not nerve growth factor-Beta, in schizophrenia patients with better response to risperidone treatment. Neuropsychobiology 59, 51-58. doi: 10 . $1159 / 000205518$

Linnarsson, S., Björklund, A., and Ernfors, P. (1997). Learning deficit in BDNF mutant mice. Eur. J. Neurosci. 9, 2581-2587. doi: 10.1111/j.1460-9568.1997. tb01687.x

Lipska, B. K., Lerman, D. N., Khaing, Z. Z., and Weinberger, D. R. (2003). The neonatal ventral hippocampal lesion model of schizophrenia: effects on dopamine and GABA mRNA markers in the rat midbrain. Eur. J. Neurosci. 18, 3097-3104. doi: 10.1111/j.1460-9568.2003.03047.x

Lohoff, F. W., Sander, T., Ferraro, T. N., Dahl, J. P., Gallinat, J., and Berrettini, W. H. (2005). Confirmation of association between the Val66Met polymorphism in the brain-derived neurotrophic factor (BDNF) gene and bipolar I disorder. Am. J. Med. Genet. B Neuropsychiatr. Genet. 139B, 51-53. doi: 10.1002/ajmg.b.30215

Lu, B., Nagappan, G., Guan, X., Nathan, P. J., and Wren, P. (2013). BDNF-based synaptic repair as a disease-modifying strategy for neurodegenerative diseases. Nat. Rev. Neurosci. 14, 401-416. doi: 10.1038/nrn3505

Lyketsos, C. G., Carrillo, M. C., Ryan, J. M., Khachaturian, A. S., Trzepacz, P., Amatniek, J., et al. (2011). Neuropsychiatric symptoms in Alzheimer's disease. Alzheimers Dement. 7, 532-539. doi: 10.1016/j.jalz.2011.05.2410

Ma, Y. L., Wang, H. L., Wu, H. C., Wei, C. L., and Lee, E. H. (1998). Brain-derived neurotrophic factor antisense oligonucleotide impairs memory retention and inhibits long-term potentiation in rats. Neuroscience 82, 957-967. doi: 10. 1016/s0306-4522(97)00325-4

Mackenzie, I. R., Neumann, M., Bigio, E. H., Cairns, N. J., Alafuzoff, I., Kril, J., et al. (2010). Nomenclature and nosology for neuropathologic subtypes of frontotemporal lobar degeneration: an update. Acta Neuropathol. 119, 1-4. doi: 10.1007/s00401-009-0612-2

Mackin, P., Gallagher, P., Watson, S., Young, A. H., and Ferrier, I. N. (2007). Changes in brain-derived neurotrophic factor following treatment with mifepristone in bipolar disorder and schizophrenia. Aust. N Z J. Psychiatry 41, 321-326. doi: 10.1080/00048670701213211

Maina, G., Rosso, G., Zanardini, R., Bogetto, F., Gennarelli, M., and BocchioChiavetto, L. (2010). Serum levels of brain-derived neurotrophic factor in drugnaive obsessive-compulsive patients: a case-control study. J. Affect. Disord. 122, 174-178. doi: 10.1016/j.jad.2009.07.009

Mattson, M. P. (2008). Glutamate and neurotrophic factors in neuronal plasticity and disease. Ann. N Y Acad. Sci. 1144, 97-112. doi: 10.1196/annals.1418.005

Mellios, N., Huang, H. S., Baker, S. P., Galdzicka, M., Ginns, E., and Akbarian, S. (2009). Molecular determinants of dysregulated GABAergic gene expression in the prefrontal cortex of subjects with schizophrenia. Biol. Psychiatry 65, 1006-1014. doi: 10.1016/j.biopsych.2008.11.019

Mill, J., Tang, T., Kaminsky, Z., Khare, T., Yazdanpanah, S., Bouchard, L., et al. (2008). Epigenomic profiling reveals DNA-methylation changes associated with major psychosis. Am. J. Hum. Genet. 82, 696-711. doi: 10.1016/j.ajhg.2008. 01.008

Minami, S. S., Min, S. W., Krabbe, G., Wang, C., Zhou, Y., Asgarov, R., et al. (2014). Progranulin protects against amyloid beta deposition and toxicity in Alzheimer's disease mouse models. Nat. Med. 20, 1157-1164. doi: 10.1038/nm. 3672

Momeni, P., DeTucci, K., Straub, R. E., Weinberger, D. R., Davies, P., Grafman, J., et al. (2010). Progranulin (GRN) in two siblings of a Latino family and in other patients with schizophrenia. Neurocase 16, 273-279. doi: 10 1080/13554790903456209

Monteleone, P., Zanardini, R., Tortorella, A., Gennarelli, M., Castaldo, E., Canestrelli, B., et al. (2006). The 196G/A (val66met) polymorphism of the BDNF gene is significantly associated with binge eating behavior in women with bulimia nervosa or binge eating disorder. Neurosci. Lett. 406, 133-137. doi: 10.1016/j.neulet.2006.07.040

Mu, J. S., Li, W. P., Yao, Z. B., and Zhou, X. F. (1999). Deprivation of endogenous brain-derived neurotrophic factor results in impairment of spatial learning and memory in adult rats. Brain Res. 835, 259-265. doi: 10.1016/s00068993(99)01592-9

Nagahama, Y., Okina, T., Suzuki, N., and Matsuda, M. (2010). Neural correlates of psychotic symptoms in dementia with Lewy bodies. Brain 133, 557-567. doi: 10. 1093/brain/awp295

Nagahara, A. H., Merrill, D. A., Coppola, G., Tsukada, S., Schroeder, B. E., Shaked, G. M., et al. (2009). Neuroprotective effects of brain-derived neurotrophic factor in rodent and primate models of Alzheimer's disease. Nat. Med. 15, 331-337. doi: 10.1038/nm.1912

Nagahara, A. H., and Tuszynski, M. H. (2011). Potential therapeutic uses of BDNF in neurological and psychiatric disorders. Nat. Rev. Drug Discov. 10, 209-219. doi: $10.1038 / \mathrm{nrd} 3366$

Nan, X., Ng, H. H., Johnson, C. A., Laherty, C. D., Turner, B. M., Eisenman, R. N., et al. (1998). Transcriptional repression by the methyl-CpG-binding protein MeCP2 involves a histone deacetylase complex. Nature 393, 386-389. doi: 10. $1038 / 30764$

Neves-Pereira, M., Mundo, E., Muglia, P., King, N., Macciardi, F., and Kennedy, J. L. (2002). The brain-derived neurotrophic factor gene confers susceptibility to bipolar disorder: evidence from a family-based association study. Am. J. Hum. Genet. 71, 651-655. doi: 10.1086/342288

Nguyen, N., Lee, S. B., Lee, Y. S., Lee, K. H., and Ahn, J. Y. (2009). Neuroprotection by NGF and BDNF against neurotoxin-exerted apoptotic death in neural stem cells are mediated through Trk receptors, activating PI3-kinase and MAPK pathways. Neurochem. Res. 34, 942-951. doi: 10.1007/s11064-008-9848-9

Okura, H., Yamashita, S., Ohama, T., Saga, A., Yamamoto-Kakuta, A., Hamada, Y., et al. (2010). HDL/apolipoprotein A-I binds to macrophagederived progranulin and suppresses its conversion into proinflammatory granulins. J. Atheroscler. Thromb. 17, 568-577. doi: 10.5551/jat.3921

Onyike, C. U., and Diehl-Schmid, J. (2013). The epidemiology of frontotemporal dementia. Int. Rev. Psychiatry 25, 130-137. doi: 10.3109/09540261.2013.776523

Peng, S., Garzon, D. J., Marchese, M., Klein, W., Ginsberg, S. D., Francis, B. M., et al. (2009). Decreased brain-derived neurotrophic factor depends on amyloid aggregation state in transgenic mouse models of Alzheimer's disease. J. Neurosci. 29, 9321-9329. doi: 10.1523/JNEUROSCI.4736-08.2009

Petersen, C. M., Nielsen, M. S., Nykjaer, A., Jacobsen, L., Tommerup, N., Rasmussen, H. H., et al. (1997). Molecular identification of a novel candidate sorting receptor purified from human brain by receptor-associated protein 
affinity chromatography. J. Biol. Chem. 272, 3599-3605. doi: 10.1074/jbc.272. 6.3599

Petkau, T. L., and Leavitt, B. R. (2014). Progranulin in neurodegenerative disease. Trends Neurosci. 37, 388-398. doi: 10.1016/j.tins.2014.04.003

Petkau, T. L., Neal, S. J., Orban, P. C., MacDonald, J. L., Hill, A. M., Lu, G., et al. (2010). Progranulin expression in the developing and adult murine brain. J. Comp. Neurol. 518, 3931-3947. doi: 10.1002/cne.22430

Petoukhov, E., Fernando, S., Mills, F., Shivji, F., Hunter, D., Krieger, C., et al. (2013). Activity-dependent secretion of progranulin from synapses. J. Cell Sci. 126, 5412-5421. doi: 10.1242/jcs. 132076

Philips, T., De Muynck, L., Thu, H. N., Weynants, B., Vanacker, P., Dhondt, J., et al. (2010). Microglial upregulation of progranulin as a marker of motor neuron degeneration. J. Neuropathol. Exp. Neurol. 69, 1191-1200. doi: 10. 1097/NEN.0b013e3181fc9aea

Phillips, H. S., Hains, J. M., Armanini, M., Laramee, G. R., Johnson, S. A., and Winslow, J. W. (1991). BDNF mRNA is decreased in the hippocampus of individuals with Alzheimer's disease. Neuron 7, 695-702. doi: 10.1016/08966273(91)90273-3

Pietroboni, A. M., Fumagalli, G. G., Ghezzi, L., Fenoglio, C., Cortini, F., Serpente, M., et al. (2011). Phenotypic heterogeneity of the GRN Asp22fs mutation in a large Italian kindred. J. Alzheimers Dis. 24, 253-259. doi: 10. 3233/JAD-2011-101704

Pirildar, S., Gönül, A. S., Taneli, F., and Akdeniz, F. (2004). Low serum levels of brain-derived neurotrophic factor in patients with schizophrenia do not elevate after antipsychotic treatment. Prog. Neuropsychopharmacol. Biol. Psychiatry 28, 709-713. doi: 10.1016/j.pnpbp.2004.05.008

Polyakova, M., Stuke, K., Schuemberg, K., Mueller, K., Schoenknecht, P., and Schroeter, M. L. (2015). BDNF as a biomarker for successful treatment of mood disorders: a systematic and quantitative meta-analysis. J. Affect. Disord. 174, 432-440. doi: 10.1016/j.jad.2014.11.044

Pruunsild, P., Kazantseva, A., Aid, T., Palm, K., and Timmusk, T. (2007). Dissecting the human BDNF locus: bidirectional transcription, complex splicing and multiple promoters. Genomics 90, 397-406. doi: 10.1016/j.ygeno. 2007.05.004

Rademakers, R., Baker, M., Gass, J., Adamson, J., Huey, E. D., Momeni, P., et al. (2007). Phenotypic variability associated with progranulin haploinsufficiency in patients with the common $1477 \mathrm{C} \rightarrow \mathrm{T}$ (Arg493X) mutation: an international initiative. Lancet Neurol. 6, 857-868. doi: 10.1016/s1474-4422(07) 70221-1

Rademakers, R., Eriksen, J. L., Baker, M., Robinson, T., Ahmed, Z., Lincoln, S. J., et al. (2008). Common variation in the miR-659 binding-site of GRN is a major risk factor for TDP43-positive frontotemporal dementia. Hum. Mol. Genet. 17, 3631-3642. doi: 10.1093/hmg/ddn257

Rapoport, J. L., Addington, A., and Frangou, S. (2005). The neurodevelopmental model of schizophrenia: what can very early onset cases tell us? Curr. Psychiatry Rep. 7, 81-82. doi: 10.1007/s11920-005-0001-z

Rascovsky, K., Hodges, J. R., Knopman, D., Mendez, M. F., Kramer, J. H., Neuhaus, J., et al. (2011). Sensitivity of revised diagnostic criteria for the behavioural variant of frontotemporal dementia. Brain 134, 2456-2477. doi: 10. 1093/brain/awr179

Ratnavalli, E., Brayne, C., Dawson, K., and Hodges, J. R. (2002). The prevalence of frontotemporal dementia. Neurology 58, 1615-1621. doi: 10.1212/wnl.58.11. 1615

Reis, H. J., Nicolato, R., Barbosa, I. G., Teixeira do Prado, P. H., RomanoSilva, M. A., and Teixeira, A. L. (2008). Increased serum levels of brain-derived neurotrophic factor in chronic institutionalized patients with schizophrenia. Neurosci. Lett. 439, 157-159. doi: 10.1016/j.neulet.2008.05.022

Renton, A. E., Majounie, E., Waite, A., Simón-Sánchez, J., Rollinson, S., Gibbs, J. R., et al. (2011). A hexanucleotide repeat expansion in C9ORF72 is the cause of chromosome 9p21-linked ALS-FTD. Neuron 72, 257-268. doi: 10. 1016/j.neuron.2011.09.010

Roberson, E. D. (2012). Mouse models of frontotemporal dementia. Ann. Neurol. 72, 837-849. doi: 10.1002/ana.23722

Rohrer, J. D., Guerreiro, R., Vandrovcova, J., Uphill, J., Reiman, D., Beck, J., et al. (2009). The heritability and genetics of frontotemporal lobar degeneration. Neurology 73, 1451-1456. doi: 10.1212/WNL.0b013e3181bf997a

Rohrer, J. D., Isaacs, A. M., Mizielinska, S., Mead, S., Lashley, T., Wray, S., et al. (2015). C9orf72 expansions in frontotemporal dementia and amyotrophic lateral sclerosis. Lancet Neurol. 14, 291-301. doi: 10.1016/S14744422(14)70233-9

Sanacora, G. (2008). New understanding of mechanisms of action of bipolar medications. J. Clin. Psychiatry 69, 22-27.

Scassellati, C., Zanardini, R., Tiberti, A., Pezzani, M., Valenti, V., Effedri, P., et al. (2014). Serum brain-derived neurotrophic factor (BDNF) levels in attention deficit-hyperactivity disorder (ADHD). Eur. Child Adolesc. Psychiatry 23, 173-177. doi: 10.1007/s00787-013-0447-1

Schoder, D., Hannequin, D., Martinaud, O., Opolczynski, G., GuyantMaréchal, L., Le Ber, I., et al. (2010). Morbid risk for schizophrenia in firstdegree relatives of people with frontotemporal dementia. Br. J. Psychiatry 197, 28-35. doi: 10.1192/bjp.bp.109.068981

Seelaar, H., Kamphorst, W., Rosso, S. M., Azmani, A., Masdjedi, R., de Koning, I., et al. (2008). Distinct genetic forms of frontotemporal dementia. Neurology 71 , 1220-1226. doi: 10.1212/01.wnl.0000319702.37497.72

Sen, S., Duman, R., and Sanacora, G. (2008). Serum brain-derived neurotrophic factor, depression and antidepressant medications: meta-analyses and implications. Biol. Psychiatry 64, 527-532. doi: 10.1016/j.biopsych.2008. 05.005

Shen, F., Smith, J. A., Chang, R., Bourdet, D. L., Tsuruda, P. R., Obedencio, G. P., et al. (2011). 5-HT(4) receptor agonist mediated enhancement of cognitive function in vivo and amyloid precursor protein processing in vitro: a pharmacodynamic and pharmacokinetic assessment. Neuropharmacology 61 , 69-79. doi: 10.1016/j.neuropharm.2011.02.026

Shinagawa, S., Nakajima, S., Plitman, E., Graff-Guerrero, A., Mimura, M., Nakayama, K., et al. (2014). Psychosis in frontotemporal dementia. J. Alzheimers Dis. 42, 485-499. doi: 10.3233/JAD-140312

Shoyab, M., McDonald, V. L., Byles, C., Todaro, G. J., and Plowman, G. D. (1990). Epithelins 1 and 2: isolation and characterization of two cysteine-rich growthmodulating proteins. Proc. Natl. Acad. Sci. U S A 87, 7912-7916. doi: 10. 1073/pnas.87.20.7912

Siuciak, J. A., Lewis, D. R., Wiegand, S. J., and Lindsay, R. M. (1997). Antidepressant-like effect of brain-derived neurotrophic factor (BDNF). Pharmacol. Biochem. Behav. 56, 131-137. doi: 10.1016/s0091-3057(96) 00169-4

Skibinski, G., Parkinson, N. J., Brown, J. M., Chakrabarti, L., Lloyd, S. L., Hummerich, H., et al. (2005). Mutations in the endosomal ESCRTIII-complex subunit CHMP2B in frontotemporal dementia. Nat. Genet. 37, 806-808. doi: $10.1038 /$ ng 1609

Sklar, P., Gabriel, S. B., McInnis, M. G., Bennett, P., Lim, Y.-M., Tsan, G., et al. (2002). Family-based association study of 76 candidate genes in bipolar disorder: BDNF is a potential risk locus. Brain-derived neutrophic factor. Mol. Psychiatry 7, 579-593. doi: 10.1038/sj.mp.4001058

Sleegers, K., Brouwers, N., Van Damme, P., Engelborghs, S., Gijselinck, I., van der Zee, J., et al. (2009). Serum biomarker for progranulin-associated frontotemporal lobar degeneration. Ann. Neurol. 65, 603-609. doi: 10. 1002/ana.21621

Snowden, J. S., Neary, D., and Mann, D. M. (2002). Frontotemporal dementia. Br. J. Psychiatry 180, 140-143. doi: 10.1192/bjp.180.2.140

Stepanichev, M., Dygalo, N. N., Grigoryan, G., Shishkina, G. T., and Gulyaeva, N. (2014). Rodent models of depression: neurotrophic and neuroinflammatory biomarkers. Biomed. Res. Int. 2014:932757. doi: 10.1155/2014/ 932757

Tanaka, T., Saito, H., and Matsuki, N. (1997). Inhibition of GABAA synaptic responses by brain-derived neurotrophic factor (BDNF) in rat hippocampus. J. Neurosci. 17, 2959-2966.

Tapia, L., Milnerwood, A., Guo, A., Mills, F., Yoshida, E., Vasuta, C., et al. (2011). Progranulin deficiency decreases gross neural connectivity but enhances transmission at individual synapses. J. Neurosci. 31, 11126-11132. doi: 10. 1523/JNEUROSCI.6244-10.2011

Teng, H. K., Teng, K. K., Lee, R., Wright, S., Tevar, S., Almeida, R. D., et al. (2005). ProBDNF induces neuronal apoptosis via activation of a receptor complex of p75 $5^{\text {NTR }}$ and sortilin. J. Neurosci. 25, 5455-5463. doi: 10.1523/jneurosci.512304.2005

Todoric, J., Handisurya, A., Perkmann, T., Knapp, B., Wagner, O., Tura, A., et al. (2012). Circulating progranulin levels in women with gestational diabetes mellitus and healthy controls during and after pregnancy. Eur. J. Endocrinol. 167, 561-567. doi: 10.1530/EJE-12-0060 
Toh, H., Chitramuthu, B. P., Bennett, H. P., and Bateman, A. (2011). Structure, function and mechanism of progranulin; the brain and beyond. J. Mol. Neurosci. 45, 538-548. doi: 10.1007/s12031-011-9569-4

Toro, C. T., Hallak, J. E., Dunham, J. S., Leite, J. P., Sakamoto, A. C., Guarnieri, R., et al. (2007). The NR1 N-methyl-D-aspartate subunit and brain-derived neurotrophic factor in temporal lobe epilepsy hippocampus: a comparison of patients with and without coexisting psychiatric symptoms. Epilepsia 48, 2352-2356. doi: 10.1111/j.1528-1167.2007.01194.x

Toyooka, K., Asama, K., Watanabe, Y., Muratake, T., Takahashi, M., Someya, T., et al. (2002). Decreased levels of brain-derived neurotrophic factor in serum of chronic schizophrenic patients. Psychiatry Res. 110, 249-257. doi: 10. 1016/s0165-1781(02)00127-0

Tramontina, J. F., Andreazza, A. C., Kauer-Sant'anna, M., Stertz, L., Goi, J., Chiarani, F., et al. (2009). Brain-derived neurotrophic factor serum levels before and after treatment for acute mania. Neurosci. Lett. 452, 111-113. doi: 10. 1016/j.neulet.2009.01.028

Tsankova, N., Renthal, W., Kumar, A., and Nestler, E. J. (2007). Epigenetic regulation in psychiatric disorders. Nat. Rev. Neurosci. 8, 355-367. doi: 10. 1038/nrn2132

Vaegter, C. B., Jansen, P., Fjorback, A. W., Glerup, S., Skeldal, S., Kjolby, M., et al. (2011). Sortilin associates with Trk receptors to enhance anterograde transport and neurotrophin signaling. Nat. Neurosci. 14, 54-61. doi: 10.1038/nn. 2689

Van Damme, P., Van Hoecke, A., Lambrechts, D., Vanacker, P., Bogaert, E., van Swieten, J., et al. (2008). Progranulin functions as a neurotrophic factor to regulate neurite outgrowth and enhance neuronal survival. J. Cell Biol. 181, 37-41. doi: $10.1083 /$ jcb.200712039

van der Zee, J., and Van Broeckhoven, C. (2011). TMEM106B a novel risk factor for frontotemporal lobar degeneration. J. Mol. Neurosci. 45, 516-521. doi: 10. 1007/s12031-011-9555-x

van Haren, N. E., Cahn, W., Hulshoff Pol, H. E., and Kahn, R. S. (2008). Schizophrenia as a progressive brain disease. Eur. Psychiatry 23, 245-254. doi: 10.1016/j.eurpsy.2007.10.013

Van Kampen, J. M., Baranowski, D., and Kay, D. G. (2014). Progranulin gene delivery protects dopaminergic neurons in a mouse model of Parkinson's disease. PLoS One 9:e97032. doi: 10.1371/journal.pone.0097032

Ventriglia, M., Bocchio Chiavetto, L., Benussi, L., Binetti, G., Zanetti, O., Riva, M. A., et al. (2002). Association between the BDNF 196 A/G polymorphism and sporadic Alzheimer's disease. Mol. Psychiatry 7, 136-137. doi: 10.1038/sj.mp.4000952

Ventriglia, M., Zanardini, R., Bonomini, C., Zanetti, O., Volpe, D., Pasqualetti, P., et al. (2013). Serum brain-derived neurotrophic factor levels in different neurological diseases. Biomed. Res. Int. 2013:901082. doi: 10.1155/2013/ 901082

Vossel, K. A., and Miller, B. L. (2008). New approaches to the treatment of frontotemporal lobar degeneration. Curr. Opin. Neurol. 21, 708-716. doi: 10. 1097/WCO.0b013e328318444d

Watts, G. D., Wymer, J., Kovach, M. J., Mehta, S. G., Mumm, S., Darvish, D., et al. (2004). Inclusion body myopathy associated with Paget disease of bone and frontotemporal dementia is caused by mutant valosin-containing protein. Nat. Genet. 36, 377-381. doi: 10.1038/ng1332

Wong, J., Hyde, T. M., Cassano, H. L., Deep-Soboslay, A., Kleinman, J. E., and Weickert, C. S. (2010). Promoter specific alterations of brain-derived neurotrophic factor mRNA in schizophrenia. Neuroscience 169, 1071-1084. doi: 10.1016/j.neuroscience.2010.05.037

Wylie, M. A., Shnall, A., Onyike, C. U., and Huey, E. D. (2013). Management of frontotemporal dementia in mental health and multidisciplinary settings. Int. Rev. Psychiatry 25, 230-236. doi: 10.3109/09540261.2013.776949

Xiu, M. H., Hui, L., Dang, Y. F., Hou, T. D., Zhang, C. X., Zheng, Y. L., et al. (2009). Decreased serum BDNF levels in chronic institutionalized schizophrenia on long-term treatment with typical and atypical antipsychotics. Prog. Neuropsychopharmacol. Biol. Psychiatry 33, 1508-1512. doi: 10.1016/j. pnpbp.2009.08.011

Yin, F., Dumont, M., Banerjee, R., Ma, Y., Li, H., Lin, M. T., et al. (2010). Behavioral deficits and progressive neuropathology in progranulin-deficient mice: a mouse model of frontotemporal dementia. FASEB J. 24, 4639-4647. doi: 10.1096/fj.10161471

Yoshimura, R., Nakano, Y., Hori, H., Ikenouchi, A., Ueda, N., and Nakamura, J. (2006). Effect of risperidone on plasma catecholamine metabolites and brain-derived neurotrophic factor in patients with bipolar disorders. Hum. Psychopharmacol. 21, 433-438. doi: 10.1002/hup.804

Zanardini, R., Fontana, A., Pagano, R., Mazzaro, E., Bergamasco, F., Romagnosi, G., et al. (2011). Alterations of brain-derived neurotrophic factor serum levels in patients with alcohol dependence. Alcohol. Clin. Exp. Res. 35, 1529-1533. doi: 10.1111/j.1530-0277.2011.01489.x

Zanardini, R., Gazzoli, A., Ventriglia, M., Perez, J., Bignotti, S., Rossini, P. M., et al. (2006). Effect of repetitive transcranial magnetic stimulation on serum brain derived neurotrophic factor in drug resistant depressed patients. J. Affect. Disord. 91, 83-86. doi: 10.1016/j.jad.2005.12.029

Zeng, Y., Zhao, D., and Xie, C. W. (2010). Neurotrophins enhance CaMKII activity and rescue amyloid-beta-induced deficits in hippocampal synaptic plasticity. J. Alzheimers Dis. 21, 823-831. doi: 10.3233/JAD-2010-100264

Zhu, J., Nathan, C., Jin, W., Sim, D., Ashcroft, G. S., Wahl, S. M., et al. (2002). Conversion of proepithelin to epithelins: roles of SLPI and elastase in host defense and wound repair. Cell 111, 867-878. doi: 10.1016/s00928674(02)01141-8

Conflict of Interest Statement: The authors declare that the research was conducted in the absence of any commercial or financial relationships that could be construed as a potential conflict of interest.

Copyright (C) 2016 Zanardini, Ciani, Benussi and Ghidoni. This is an open-access article distributed under the terms of the Creative Commons Attribution License (CC BY). The use, distribution and reproduction in other forums is permitted, provided the original author(s) or licensor are credited and that the original publication in this journal is cited, in accordance with accepted academic practice. No use, distribution or reproduction is permitted which does not comply with these terms. 